\title{
Addressing the road safety results impasse through an Outcome-Based Approach in the state of Penang, Malaysia.
}

Nur Sabahiah Abdul Sukor*, Ahmad Farhan Mohd Sadullah2

1 School of Civil Engineering, University Sains Malaysia, 14300, Nibong Tebal, Penang, Malaysia, cesabahiah@usm.my 2 Schoolof Civil Engineering, University Sains Malaysia, 14300, Nibong Tébal, Penang, Malaysia, cefrhn@usm.my

This is an open access article distributed under the Creative Commons Attribution License, which permits unrestricted use, distribution, and reproduction in any medium, provided the original work is properly cited

\section{ART I C LE DETAILS}

\section{Article history:}

Received 12 September 2016

Accepted 20 December 2016

Available online 10 January 2017

\section{Keywords:}

road safety planning

outcome-based approach,

Decade of Action, road safety pillars

\section{A B S T R A C T}

Despite the many road safety initiatives introduced in the state of Penang in Malaysia, the results have not been encouraging. This is especially critical when the expectation of the Decade of Action for Road Safety is to halve all road safety performance by the year 2020 .

The conventional intervention-based approach has been proven to have limited success and potential for the expected more drastic results. A critical analysis on the matter suggested that the passion for road safety results had dwindled as many players approach them as only processes that may not necessarily provide us with aspired road safety outcomes. This paper discusses the development of Road Safety Strategic Plan for Penang State through the outcome based approach. This pioneering effort begins by defining the appropriate goals for 2020 and followed by describing four principal strategic pillars. The pillars are changing attitude, forgiving roads, safer for motorcycles and enabling data and information. Each pillar has its own targeted outcomes, making a total of 28 outcomes identified. The appropriate activities and interventions in order to achieve the outcome were also recommended. The remainder of the paper also discusses the implementation plan suggested to the authorities and decision makers and other players in order to achieve the road safety targeted outcomes. Early results will also be highlighted in the paper.

\section{Introduction}

In 2009, the World Health Organization (WHO) reported that more than 3,000 deaths occur on a daily basis and that nearly 1.3 million people die annually as a result of traffic collisions globally, thus making road accidents an international public health priority [1]. As a result, in 2010 the United Nations Road Safety Collaboration (UNSRC) launched the Decade of Action for Road Safety 2011-2020, with the aim of stabilizing and then reducing global road accident fatality trends by 2020 [2]. In addition, the global action plan recommends that countries need to develop their own national action plan for the decade such that it is consistent with or can be carried forward into the regional plan.

In response to the UNSRC's action plan, Malaysia has also introduced many programs and initiatives to reduce the rate of road accidents in this country. For example, the Road Safety Plan of Malaysia 2006 - 2010 and the Road Safety Plan of Malaysia 2014 - 2020 have been established by the Malaysian Institute of Road Safety (MIROS) to serve as guidelines for all stakeholders and road safety authorities in order to achieve the reduction target $[3,4]$. Until today, many actions, such as the establishment of a National Accident Database System, the Five Stages of Road Safety Auditing, the National Blackspot Program, the Road Safety Research and Evaluation, the Conspicuity Initiatives for Motorcycles, the National Targeted Road Safety Campaign, the Revision of the Road Transport Act (1999 Revision), the Integrated Enforcement, the New Helmet Standard MS1 1991 and the New Children's Motorcycle Helmet Initiatives are among the numerous initiatives that have been implemented in Malaysia [5,6]

Even though the findings of many studies on the effectiveness of the road safety intervention programmes have reported positive results with regard to the programmes and actions in the national road safety plan [7,8,9], but still Malaysia has a long way to go to achieve its target of reducing the number of road accidents. This may be because those intervention programmes were actually had not been successful in tackling the core issues or problems concerning road safety. It has been reported that some initiatives or countermeasures might heighten the perception of being involved in road accidents for a short period of time only. [10,11].
Therefore, the Penang State Government has made an effort to establish the Penang Road Safety Strategic Plan 2014-2020 [12] that corresponds with the Malaysian Road Safety Plan 2014-2020 and the Decade of Action for Road Safety. However, the strategic plan is aimed at complementing the outcome-based approach instead of interventionbased approach. Outcome-based approach is a strategic plan that designed after the main problems and issues have been recognized together with the target on percentages of reduction of the specific problems that have been identified. Compare to intervention-based approach, the outcome based-approach has more clear objective.

Ultimately, this paper aims to foster road safety countermeasures in the state of Penang through the outcome-based approach. There are 31 outcomes that have been identified as yardsticks of road safety actions for interested parties in Penang. Based on these outcomes, it is hoped that the road safety implementation plans in Penang can be more effective in reducing the rate of road accidents in this state.

\section{METHOD}

\subsection{Addressing Current Road Safety Performance and Target}

In order to come out with an outcome based approach strategic plan, current road safety performance is needed to be addressed. For current conditions, it is claimed that there is substantial improvement in road safety performance in Malaysia since the launching of the Road Safety Plan Malaysia 2006 - 2010, that also reflected in many regions in Malaysia, including Penang. However, the statistical data in Table 1 shows that the number of road crashes and fatalities continue to increase year by year for the state of Penang as well as for the whole of Malaysia. This contradicts the claim by many road safety studies that the implementation of conventional plans has been effective. 
Table 1 Comparison between Road Safety Data for Penang and National Data from 2005 until 2012 (Penang Road Safety Strategic Plan 2014-2020)

\begin{tabular}{|c|c|c|c|c|c|c|c|c|}
\hline $\begin{array}{c}\text { PENAN } \\
\text { G }\end{array}$ & $\begin{array}{c}200 \\
5\end{array}$ & $\begin{array}{c}200 \\
6\end{array}$ & $\begin{array}{c}200 \\
7\end{array}$ & $\begin{array}{c}200 \\
8\end{array}$ & $\begin{array}{c}200 \\
9\end{array}$ & $\begin{array}{c}201 \\
0\end{array}$ & $\begin{array}{c}201 \\
1\end{array}$ & $\begin{array}{c}201 \\
2\end{array}$ \\
\hline Road & 30,9 & 32,5 & 33,8 & 34,0 & 33,7 & 34,3 & 37,1 & 37,8 \\
\hline Crashes & 34 & 73 & 81 & 49 & 19 & 06 & 58 & 51 \\
\hline $\begin{array}{l}\text { Fatalitie } \\
\mathrm{s}\end{array}$ & 370 & 381 & 376 & 354 & 395 & 370 & 392 & 400 \\
\hline Vehicle & 1,58 & 1,68 & 1,78 & 1,89 & 1,99 & 2,10 & 2,21 & 2,32 \\
\hline Registra & 4,82 & 6,74 & 8,69 & 7,82 & 4,65 & 7,23 & 3,74 & 7,08 \\
\hline tion & 7 & 2 & 1 & 1 & 8 & 1 & 7 & 7 \\
\hline $\begin{array}{l}\text { Fatality } \\
/ 10 \mathrm{k} \\
\text { Veh }\end{array}$ & 2.33 & 2.26 & 2.10 & 1.87 & 1.98 & 1.76 & 1.77 & 1.72 \\
\hline $\begin{array}{l}\text { Road } \\
\text { Crash/ } \\
\text { 10k Veh }\end{array}$ & $\begin{array}{c}195 . \\
19\end{array}$ & $\begin{array}{c}193 . \\
11\end{array}$ & $\begin{array}{c}189 . \\
42\end{array}$ & $\begin{array}{c}179 . \\
41\end{array}$ & $\begin{array}{c}169 . \\
05\end{array}$ & $\begin{array}{c}162 . \\
80\end{array}$ & $\begin{array}{c}167 . \\
85\end{array}$ & $\begin{array}{c}162 . \\
65\end{array}$ \\
\hline New & 32,4 & 33,0 & 29,7 & 30,9 & 30,3 & 31,8 & 31,3 & 31,8 \\
\hline Driver & 08 & 59 & 81 & 77 & 65 & 33 & 45 & 39 \\
\hline NATIO & 200 & 200 & 200 & 200 & 200 & 201 & 201 & 201 \\
\hline NAL & 5 & 6 & 7 & 8 & 9 & o & 1 & 2 \\
\hline $\begin{array}{l}\text { Road } \\
\text { Crashes }\end{array}$ & $\begin{array}{l}328, \\
264\end{array}$ & $\begin{array}{l}341, \\
252\end{array}$ & $\begin{array}{l}363, \\
319\end{array}$ & $\begin{array}{l}373, \\
071\end{array}$ & $\begin{array}{l}397, \\
330\end{array}$ & $\begin{array}{l}414, \\
421\end{array}$ & $\begin{array}{l}449, \\
040\end{array}$ & $\begin{array}{l}462 \\
426\end{array}$ \\
\hline $\begin{array}{l}\text { Fatalitie } \\
\mathrm{s}\end{array}$ & $\begin{array}{c}6,18 \\
8\end{array}$ & $\begin{array}{c}6,28 \\
7\end{array}$ & $\begin{array}{c}6,28 \\
2\end{array}$ & $\begin{array}{c}6,52 \\
7\end{array}$ & $\begin{array}{c}6,74 \\
5\end{array}$ & $\begin{array}{c}6,87 \\
2\end{array}$ & $\begin{array}{c}6,87 \\
7\end{array}$ & $\begin{array}{c}6,91 \\
7\end{array}$ \\
\hline Vehicle & 14,8 & 15,7 & 16,8 & 17,9 & 19,0 & 20,1 & 21,4 & 22,7 \\
\hline Registra & 16,4 & 90,7 & 13,9 & 71,9 & 16,7 & 88,5 & 01,2 & 02,2 \\
\hline tion & 07 & 32 & 43 & 01 & 82 & 65 & 69 & 21 \\
\hline $\begin{array}{l}\text { Fatality } \\
/ 10 \mathrm{k} \\
\text { Veh }\end{array}$ & 4.18 & 3.98 & 3.74 & 3.63 & 3.55 & 3.40 & 3.21 & 3.05 \\
\hline $\begin{array}{l}\text { Road } \\
\text { Crash/ } \\
10 \mathrm{k} \text { Veh }\end{array}$ & $\begin{array}{c}221 . \\
55\end{array}$ & $\begin{array}{c}216 . \\
11\end{array}$ & $\begin{array}{c}216 . \\
08\end{array}$ & $\begin{array}{c}207 . \\
59\end{array}$ & $\begin{array}{c}208 . \\
94\end{array}$ & $\begin{array}{c}205 . \\
28\end{array}$ & $\begin{array}{c}209 . \\
82\end{array}$ & $\begin{array}{c}203 . \\
69\end{array}$ \\
\hline $\begin{array}{l}\text { New } \\
\text { Driver }\end{array}$ & $\begin{array}{l}427, \\
991\end{array}$ & $\begin{array}{l}423, \\
094\end{array}$ & $\begin{array}{l}416, \\
499\end{array}$ & $\begin{array}{l}457, \\
613\end{array}$ & $\begin{array}{l}475 \\
618\end{array}$ & $\begin{array}{l}538, \\
948\end{array}$ & $\begin{array}{l}527, \\
198\end{array}$ & $\begin{array}{l}540 \\
391\end{array}$ \\
\hline
\end{tabular}

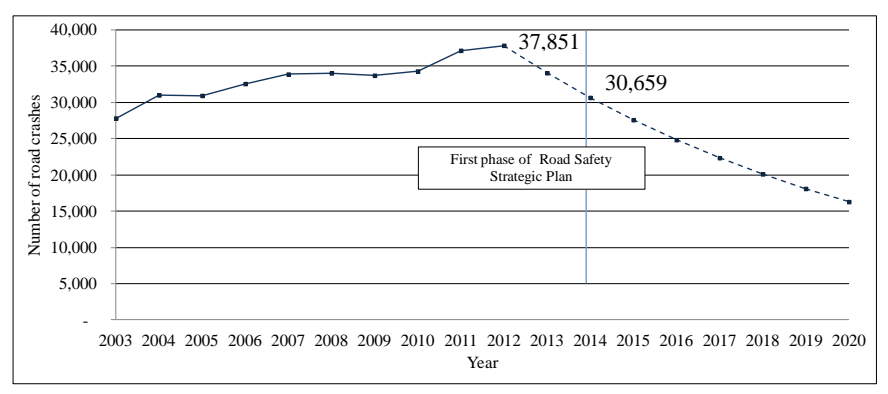

Fig.1 Target for road crash reduction in Penang from 2012-2020 (Penang Road Safety Strategic Plan 2014-2020)
With the intention to set the road safety's target for Penang, the reduction in the number of accidents was calculated by using the road safety data in 2012 as the baseline. The estimates for road crash reduction from 2012 to 2020 are shown in Figure 1. The first phase of the Road Safety Strategic Plan for the state of Penang was implemented in 2014 which consisted of establishment of serious injuries data and information in Penang. In order to achieve the target of the strategic plan, the first phase activity were more focusing on i) to improve the attitude among data owners (such as PDRM, hospital, municipal council etc) on the importance of data keeping and data sharing ii) to stimulate the effort to establish all baseline data in parallel with analysing the progress data.

\subsection{Establishment of Four Pillars}

Throughout 2014, an extensive series of meetings and workshops were held with representatives of government bodies, non-governmental organizations, researchers and interest groups to identify the current road safety issues and problems in Penang. The findings from the workshops acknowledged thirty-one outcomes from four strategic pillars that need to be tackled by all the relevant agencies and community partners. These strategic pillars are the main elements in the house of the Road Safety Strategic Plan for Penang State, as shown in Figure 2.

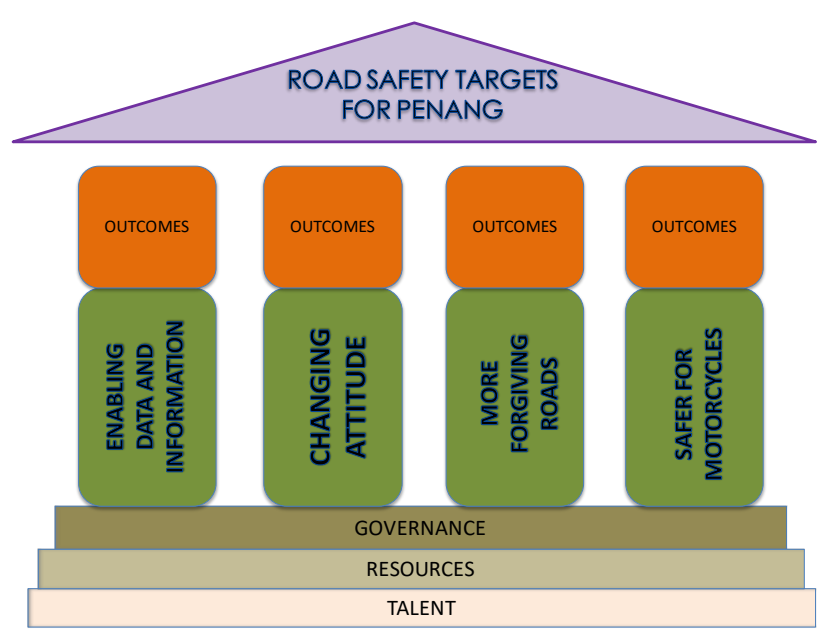

Fig.2 The house of the Road Safety Strategic Plan for Penang State (Penang Road Safety Strategic Plan 20142020)

The house also comprises a roof, that encapsulates the ultimate goal of the road safety's target for Penang, which is to achieve a reduction of at least $10 \%$ from the previous year in terms of the number of fatalities, number of serious injuries, number of crashes, number of motorcycle fatalities and number of pedestrian fatalities; and three foundations, namely governance, resources and talent.

The most important elements in this framework are the strategic pillars that underpin the mission and approach to fulfil the road safety target in Penang. These pillars are: Pillar 1 - Enabling Data and Information, Pillar 2 - Changing Attitude, Pillar 3 - More Forgiving Roads, and Pillar 4 - Safer for Motorcycles. Programs and intervention plans have been identified for each pillar in order to comply with the objectives of the pillar.

This strategic plan also outlines a comprehensive set of fifty-two activities that correspond with the outcomes from the workshops. The activities that have been identified also try to engage the participation of all stakeholders in 
order to ensure that the road safety plan is optimized in this state. In addition, the establishment of this strategic plan is expected to coordinate all the actions, activities, programs and interventions that relate to road safety with the aim of achieving the target of road accident reduction in Penang.

\section{RESULTS AND DISCUSSION}

An outcome-based or performance-based approach is believed to offer a powerful and appealing way of reforming and managing the implementation of road safety plans in Penang. This section presents a brief outline of the outcomes of the four strategic pillars in the Road Safety Strategic Plan for Penang. The level of implementation of the strategic plan is suggested to be divided into two levels. First, the implementation will be focused on the community level, at the stage of state legislative assemblies (DUN) and districts. Second, the implementation will be focused towards the respective owners of state legislative assemblies (DUN), districts and state level.

The Enabling Data and Information Pillar is the most crucial pillar in this strategic plan. Without the appropriate data on crashes and fatalities, it would probably be impossible to measure the effectiveness of other initiatives. Therefore, the initial step in this strategic plan is to achieve the eight outcomes in Pillar 1. Up to the day when this paper was written, the establishment of capacity building was still in progress. Meanwhile the other pillars were automatically associated with Pillar 1.

The stakeholders, who include the Penang State authorities, road safety practitioners, enforcement officers, hospitals, politicians, and interested parties, have formed a WhatsApp group. These stakeholders are disseminating information on road crashes, fatalities, road users' attitudes and complaints to enable the responsible bodies, who are also members of this group, to respond automatically. Figure 3 below shows the road crash information that is being shared in this WhatsApp group. The outcomes in Pillar 1 will also influence the outcomes in the other pillars. Even though, for the time being, not all the outcomes have been fulfilled, the responsible bodies are making continuous progress with regard to the performance of the initiatives. Table 2 shows the outcomes that needed to be achieved in each pillar.

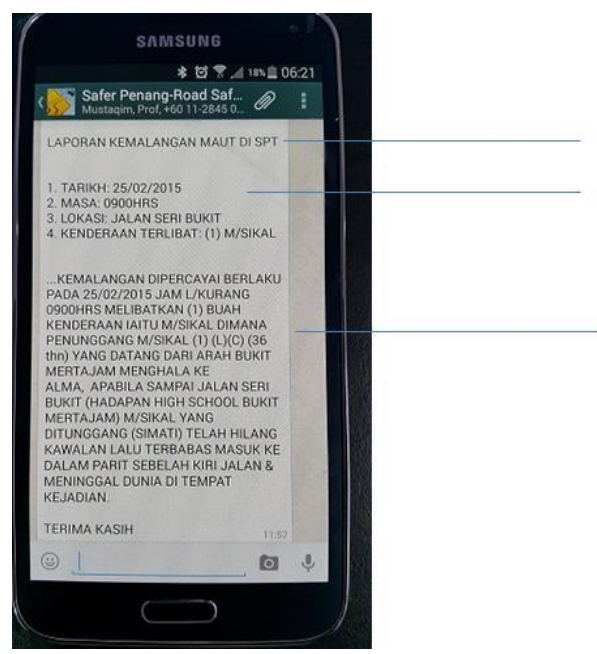

Title

Date, Time, Location anc Type of accident

Report

Figure 3: Example of road crash report through the WhatsApp Group

\begin{tabular}{|c|c|}
\hline Pillar & Outcomes \\
\hline $\begin{array}{l}\text { Enabling } \\
\text { data and } \\
\text { information }\end{array}$ & $\begin{array}{ll}\text { 1. } & \begin{array}{l}\text { Daily or monthly data on injuries and } \\
\text { fatalities }\end{array} \\
\text { 2. } & \begin{array}{l}\text { Data on monthly traffic offences (speeding, } \\
\text { neglecting to use helmet, running red lights, }\end{array} \\
\text { etc.) } \\
\text { 3. } \begin{array}{l}\text { Monthly data on new registration of vehicles } \\
\text { and drivers }\end{array} \\
\text { 4. } \begin{array}{l}\text { Monthly data on roadworthiness of new } \\
\text { vehicles }\end{array} \\
\text { 5. Analysis of important road safety indicators } \\
\text { 6. Dissemination of information } \\
\text { 7. Data on emergency response team } \\
\text { 8. Capacity building on data collection among } \\
\text { 9gencies } \\
\text { 9. } \begin{array}{l}\text { Databank of public transport vehicles and } \\
\text { drivers }\end{array} \\
\text { 10. Reduction of casualties and fatalities due to } \\
\text { sub-standard quality material }\end{array}$ \\
\hline $\begin{array}{l}\text { Changing } \\
\text { Attitudes }\end{array}$ & $\begin{array}{l}\text { 1. Compliance with traffic rules amongst road } \\
\text { users } \\
\text { 2. Increasing number of roadworthy vehicles } \\
\text { 3. Increasing awareness towards road safety } \\
\text { within the community } \\
\text { 4. Reduction in the number of repeat offenders } \\
\text { 5. Good coordination among the authorities } \\
\text { 6. Upgrading public transport services } \\
\text { 7. Good road maintenance with zero defects } \\
\text { aim } \\
\text { 8. Good design of roads, strong safety } \\
\text { precautions with 'error-proof approach } \\
\text { 9. Pro-activeness towards addressing road } \\
\text { defects, improving blackspots, and zero } \\
\text { hazards during construction } \\
\text { 10. Reduction in the number of private vehicles } \\
\text { on the road and increasing usage of public } \\
\text { transport } \\
\text { 11. Implementation and enforcement plan for } \\
\text { all appropriate supporting activities }\end{array}$ \\
\hline $\begin{array}{l}\text { More } \\
\text { Forgiving } \\
\text { Roads }\end{array}$ & 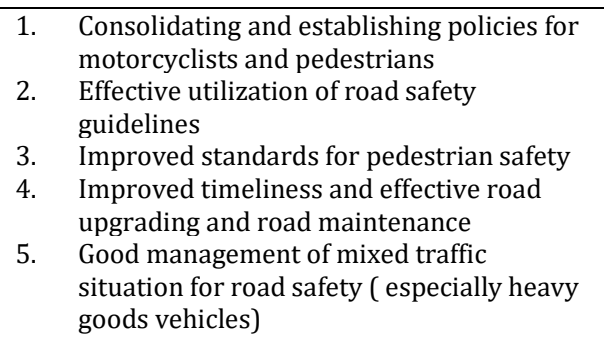 \\
\hline $\begin{array}{l}\text { Safer For } \\
\text { Motorcycles }\end{array}$ & $\begin{array}{ll}1 . & \text { Reduce fatalities due to non-helmet } \\
\text { wearing } \\
\text { 2. }\end{array}$ \\
\hline
\end{tabular}

\section{CONCLUSION}

An efficient road safety strategic plan is required in order to further reduce the level of crashes and casualties. In this respect, policy makers or the state government need to select optimal countermeasures, and this study 
has revealed the initiatives that have been carried out by the State Government of Penang. In this study, a strategic plan that uses the outcome-based approach is optimistically believed to be able to assist in prioritizing the road safety actions and initiatives in Penang State, albeit the implementation of the approach is still at an early stage. The outcomebased approach guidelines in the strategic plan should be used regularly, in order to understand the effectiveness of the plan.

It is also believed that the outcome-based approach offers many advantages for achieving the target of road accident reduction. It emphasizes the relevance in road safety countermeasures, and can provide a clear and unambiguous framework for the road safety strategic plan. It encourages all stakeholders to share their responsibilities and roles in road safety and it can guide the effective assessment and evaluation of road safety compared to the conventional approach. In the outcome-based approach, the sort of actions that need to be taken to tackle road safety problems are being addressed by prioritizing the crucial components of the problem first.

In addition, the implementation of the strategic plan needs a team effort, and every responsible party must play their the road safety strategic plan. For example the state government may introduce new policy or strengthen existing policy, but still need to provide the effective enforcement mechanism to ensure that the plan works. Meanwhile, many of the road safety issues need the authorities' concern especially that relates to road planning, design and maintenance. Therefore the strategic plan is hoped that the relevant authority can be more focus and can provide better justification for all road safety issues. Moreover, the involvement of the community (community-based intervention), either by the community leaders or the community themselves should be carried out effectively.

\section{ACKNOWLEDGEMENT}

This study is funded by the Penang State Government. The authors gratefully acknowledge the Traffic Management Unit under the Local Government Division of the Penang State Secretariat for the endless commitment and support through the process of establishing the Road Safety Strategic Planning.

\section{REFERENCES}

[1] World Health Organization (Ed.). Global status report on road safety: time for action. World Health Organization. (2009)

[2] World Health Organization. WHO global status report on road safety 2013: supporting a decade of action. World Health Organization. (2013)

[3] Malaysia Road Safety Department. Road Safety Plan of Malaysia 2006-2010. Ministry of Transport Malaysia (2006)

[4] Malaysia Road Safety Department Road Safety Plan of Malaysia 201-2020. Ministry of Transport Malaysia. (2014)

[5] S. Rohayu, H. Hizal Hanis, R.S. Radin Umar. Development of national road safety targets and intervention initiatives in Malaysia. Transport and Communications Bulletin for Asia and the Pacific , (2009) No 79

[6] M. N Mustafa. Overview of current road safety situation in Malaysia.Highway Planning Unit (Road Safety Section, Ministry of Works) 2005, 5-9.

[7] U. R Radin, M. G. Mackay, B. L. Hills, Modelling of conspicuityrelated motorcycle accidents in Seremban and Shah Alam, Malaysia. Accident Analysis \& Prevention, (1996) 28(3), 325-332

[8] R. S. Radin Umar, Motorcycle safety programmes in Malaysia: how effective are they?. International journal of injury control and safety promotion, (2006). 13(2), 71-79.

[9] H Azhar,. A.,, Yahaya, \& S. V. Wong, Child helmet efficacy for motorcycle use in Malaysia. MRev04/2009, (2009). Kuala Lumpur.

[10] S., Kulanthayan, R. R., Umar, H. A., Hariza, M. M., Nasir, S Harwant. Compliance of proper safety helmet usage in motorcyclists. Medical Journal of Malaysia, (2000). 55(1), 40-44.

[11] P. Puvanachandra, S Kulanthayan,. A. A, HyderA Game of Chinese Whispers in Malaysia Contextual Analysis of Child Road Safety Education. Qualitative health research(2012). 22(11), 14761485.

[12] Penang Road Safety Strategic Plan 2014-2020. (2014) Penang State Government

[13] W. Murray. Evaluating Occupational Road Safety Programmes: A Process and Outcomes Based Approach. RoSPA Congress 2009 (2010) Interactive Driving Systems. 